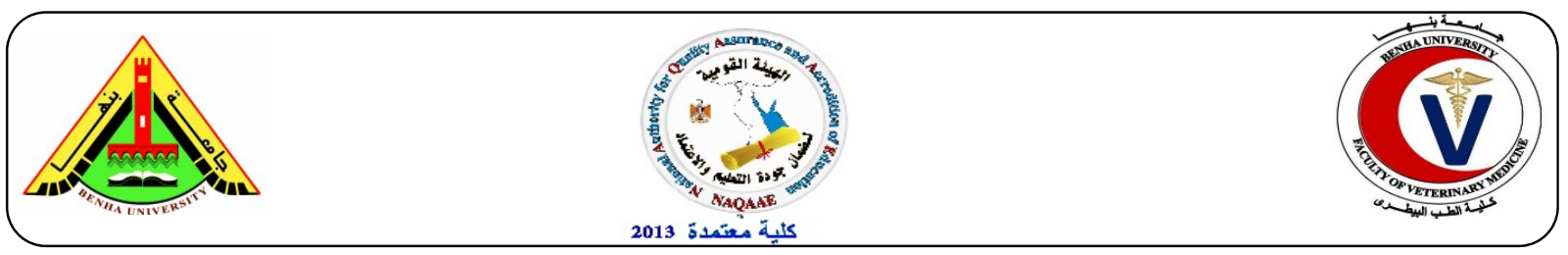

\title{
The bacteriological status of retail cheese in Zagazig city, Egypt
}

\author{
Seham El-Badry and Amal Raslan
}

Educational Veterinary Hospital, Faculty of Veterinary Medicine, Zagazig University, Zagazig, Egypt

\section{A B S T R A C T}

Cheese is one of the most popular dairy products in Egypt. It supplies the body with protein, fat, vitamins and minerals. Cheese may be exposed to bacterial contamination during manufacture, distribution and/or storage. This study was undertaken to investigate the bacteriological status of different cheese types marketed in Zagazig city, Egypt. The obtained results showed that Roumy cheese had the highest total mesophilic and psychrophilic counts followed by white, soft and cheddar cheese types. Furthermore, the coliforms count and prevalence of different serotypes of $E$. coli in cheese samples were detected. In addition, the expression of shiga-toxin producing genes (stx1 \& stx2) in the identified E. coli serotypes was screened using multiplex PCR. The obtained results revealed that only E. coli $O_{127}: H_{6}$ had expressed both stx $1 \&$ stx 2 toxin producing genes, while $E$. coli $O_{111}: H_{4}$ had expressed only stx 1 gene, however, both E. coli $O_{124}: H$ and $O_{55}: H_{7}$ had expressed stx2 gene. The public health importance of shiga-toxin producing E. coli was detected.

Key words: Bacteria, Cheese, E. coli, Health hazards.

(http://www.bvmj.bu.edu.eg)

(BVMJ-31(2):267-271, 2016)

\section{INTRODUCTION}

$\mathrm{C}$ heese is one of the most famous dairy products worldwide. It contains many nutrients including protein, fat, and vitamins as vitamin $\mathrm{D}$ and minerals as calcium, magnesium, and potassium. Cheese intake is related to improved bone health and lower risk of cardiovascular disease and hypertension (Ranganathan et al., 2005). Bacterial contamination of dairy products is of a particular importance in the field of food industry. The microbial contamination of milk products, particularly cheeses is caused by different microorganisms present in the environment of cheese factories, like walls and shelves of ripening rooms, air, equipment, water, milk and brine (Jay, 1992). Many factors control the bacterial growth in cheese such as moisture, $\mathrm{pH}$, oxygen, substrate content and the hygienic habits of the cheese processors (Anonymous (Anonymous, 2000).

Microbiological examination of food samples is generally recommended to validate and verify the efficiency of food safety and quality control. Therefore, the microbiological testing at various stages of food production is relevant to understand the characteristic trends in distribution of microbiological contamination (International Commission on Microbiological Specifications for Foods (ICMSF), 1996). E. coli is a major component of the normal intestinal flora of animals which, if found in food of animal origin indicates fecal contamination. Shiga toxin producing E. coli are classified into two broadly categorized as shiga toxin producing E. coli (STEC) $\mathrm{O}_{157}$ and non- $\mathrm{O}_{157}$ STEC. While more than 100 serotypes of STEC have been associated with human disease, E. coli $\mathrm{O}_{157}$ causes 50 to $90 \%$ of cases, with most of the remaining cases caused by just six serotypes: $\mathrm{O}_{26}$, $\mathrm{O}_{45}, \mathrm{O}_{103}, \mathrm{O}_{111}, \mathrm{O}_{121}$ and $\mathrm{O}_{145}$ (Scallan (Scallan et al., 2011) et al., 2011). Cheese made from unpasteurized milk has been frequently implicated as the vehicle of transmission in outbreaks of many infectious intestinal diseases, including $E$. coli $\mathrm{O}_{157}: \mathrm{H}_{7}$ (Anonymous, 2000).

Thus, this study was undertaken to estimate the bacterial quality (total mesophilic and psychrophilic bacterial count, as well as coliforms count) of three cheese types commonly consumed by Egyptian population. The examined cheese types included roumy, cheddar and white soft cheese. Furthermore, the prevalence of STEC in the examined cheese samples was also tested. The public health importance of STEC was also discussed.

\section{MATERIALS AND METHODS}

\subsection{Collection of cheese Samples}


Seventy-five random samples of three cheese types namely, Roumy, cheddar and white cheese (twenty-five of each) were collected from different supermarkets in Zagazig city, Egypt. Samples were identified, packed and transferred to the laboratory in an icebox and subjected to bacteriological examination.

\subsection{Preparation of samples}

Twenty-five grams from each cheese sample were aseptically homogenized in $225 \mathrm{ml}$ of sterile buffered peptone water $0.1 \%$ at $2500 \mathrm{rpm}$ for $2 \mathrm{~min}$ using a sterile homogenizer (type M-P3-302, mechanic, precyzina, Poland). Such homogenate represents the dilution of $10^{-1}$, and then decimal dilutions were done (American Public Health Association (APHA), 2001).

\subsection{Determination of the total mesophilic count}

One $\mathrm{ml}$ from each of the prepared dilutions was taken and transferred into two separate sterile petri dishes to which approximately $12-15 \mathrm{ml}$ of sterile melted and tempered $\left(45^{\circ} \mathrm{C}\right)$ plate count agar (Oxoid) were added (APHA, 2001). After thorough mixing, the inoculated plates were allowed to solidify before incubation at $37{ }^{\circ} \mathrm{C}$ for $24 \mathrm{hrs}$. The plates containing 30-300 pin point colonies were calculated and recorded for TBC/g. as follow:

$\mathrm{TBC} / \mathrm{g}$. = average No. of colonies $\times$ reciprocal of dilution

Counted colonies expressed as $\log \mathrm{cfu} / \mathrm{g}$.

\subsection{Determination of the total psychrophilic count}

The pour plate technique recommended by APHA (2001) was applied using standard plate count agar medium and incubated at $7{ }^{\circ} \mathrm{C}$ for 10 days. Results were calculated and recorded. Counted colonies expressed as $\log \mathrm{cfu} / \mathrm{g}$.

\subsection{Determination of total Coliform count (MPN)}

Three tubes most probable number (MPN) method recommended (APHA, 2001) were adopted. In brief, one $\mathrm{ml}$ of each dilution was used to inoculate separately into three test tubes containing MacConkey broth with inverted Durham's tubes. The inoculated tubes were incubated at $37{ }^{\circ} \mathrm{C}$ for $24-48$ hrs. Positive tubes showing acid (yellow color) and gas production in inverted Durham's tubes were recorded. The most probable number of coliforms was calculated according to the recommended tables.

\subsection{Isolation of Escherichia coli}

A loopfull from each positive tube (acid and gas) of MacConkey broth which firstly incubated at 44 $\pm 0.5{ }^{\circ} \mathrm{C}$ for $48 \mathrm{hrs}$. was streaked onto Eosin Methylene blue (EMB) agar (APHA, 2001). The inoculated plates were incubated at $37^{\circ} \mathrm{C}$ for 24 hrs. Typical colonies of E. coli appear greenish, metallic with dark purple center. Suspected colonies were purified and subcultured onto nutrient agar slope and incubated for further investigations. Identification of isolates was done according to the method described before (APHA, 2001) based on staining and biochemical tests (Catalase, Oxidase, Indol, Methyl Red, VP test, Citrate utilization, Nitrate reduction, Urease, H2S production, Gelatin liquefaction and Eijkman test).

\subsection{Serodiagnosis of E. coli}

The confirmed E. coli isolates were serologically identified according to Kok et al. (1996) by using rapid diagnostic E. coli antisera sets (Difco, Detroit, MI, USA) for diagnosis of the Enteropathogenic types.

\subsection{DNA preparation}

Bacterial DNA was extracted from each of glycerol stock serodiagnosed E. coli according to the method described before (Darwish et al., 2015).

Detection of shiga-toxin producing genes in the identified isolates: Detection of shiga-toxin producing genes in the identified $E$. coli isolates was carried out using multiplex polymerase chain reaction (multiplex PCR). Primer sequences and amplified products sizes were shown in table 1 . The amplification was performed on a Thermal Cycler (Master cycler, Eppendorf, Hamburg, Germany). PCR assays were carried out using the method of Dhanashree and Mallya (2008) in $1 \mathrm{ml}$ of nucleic acid template prepared by using reference EHEC isolates

Table 1 Primer sequences of Shiga-toxin producing genes

\begin{tabular}{llcc}
\hline Primer & \multicolumn{1}{c}{ Oligonucleotide sequence $\left(5^{\prime} \rightarrow 3^{\prime}\right)$} & Product size (bp) & References \\
\hline stx1 (F) & 5' ACACTGGATGATCTCAGTGG '3 & \multirow{2}{*}{614} & Dhanashree and Mallya (2008) \\
Stx1 (R) & 5' CTGAATCCCCCTCCATTATG '3 & & \\
Stx2 (F) & 5' CCATGACAACGGACAGCAGTT '3 & \multirow{2}{*}{779} & Dhanashree and Mallya (2008) \\
Stx2 (R) & 5' CCTGTCAACTGAGCAGCACTTTG '3 & & \\
\hline
\end{tabular}


(approximately $30 \mathrm{ng}$ of DNA), $10 \mathrm{mM}$ Tris- $\mathrm{HCl}$ ( $\mathrm{pH}$ 8.4), $10 \mathrm{mM} \mathrm{KCl}, 3 \mathrm{mM} \mathrm{MgCl} 2 ; 2 \mathrm{mM}$ concentrations of each primer, $0.2 \mathrm{mM}$ concentrations of each 29-deoxynucleoside 59triphosphate, and $4 \mathrm{U}$ of AmpliTaq DNA polymerase (Perkin-Elmer). Amplification conditions consisted of an initial $95^{\circ} \mathrm{C}$ denaturation step for 3 min followed by 35 cycles of $95^{\circ} \mathrm{C}$ for $20 \mathrm{secs}, 58^{\circ} \mathrm{C}$ for $40 \mathrm{~s}$, and $72{ }^{\circ} \mathrm{C}$ for $90 \mathrm{sec}$. The final cycle was followed by $72{ }^{\circ} \mathrm{C}$ incubation for 5 min. The reference strains were E. coli O157:H7 Sakai (positive for stx1\& stx2) and E. coli $\mathrm{K} 12 \mathrm{DH} 5 \alpha$ (a nonpathogenic negative control strain) that does not possess any virulence gene. Amplified DNA fragments were analyzed by $2 \%$ of agarose gel electrophoresis (Applichem, Germany, GmbH) in 1x TBE buffer stained with Ethedium bromide and captured as well as visualized on UV transilluminator. A 100 bp plus DNA Ladder (Qiagen, Germany, GmbH) was used to determine the fragment sizes

\subsection{Statistical analysis}

All values are expressed as means $\pm \mathrm{SD}$, and all measurements were carried out in duplicates. Bacterial counts were converted into base logarithms of colony forming units per $g$ of cheese samples $(\log \mathrm{cfu} / \mathrm{g})$. Statistical significance was evaluated using the Tukey-Kramer HSD test (JMP statistical package; SAS Institute Inc., Cary, NC). In all analyses, $P<0.05$ was taken to indicate statistical significance.

\section{RESULTS}

The recorded mean \pm SD $(\log \mathrm{cfu} / \mathrm{g})$ values were $5.84 \pm 0.28,5.00 \pm 0.21$ and $4.69 \pm 0.15$ in the examined Roumy, white soft and cheddar cheese, respectively (fig. 1). Roumy cheese had significantly higher total mesophilic count followed by white cheese and finally cheddar one. Similarly, Roumy cheese had the highest psychrophilic count $(4.69 \pm 0.11)$, followed by white cheese $(3.69 \pm 0.18)$ and cheddar cheese $(3.60 \pm 0.22)$, respectively (fig. 2). The results shown in (fig. 3) declared that the mean value of MPN of coliforms in the examined cheese samples was the highest in Roumy cheese $(4.31 \pm 0.14)$, followed by white soft cheese $(3.85 \pm 0.21)$, then cheddar cheese $(3.47 \pm 0.25)$. The prevalence of $E$. coli in the examined cheese samples was also tested and the recorded results showed that the incidence of $E$. coli was $40 \%, 20 \%$ and $8 \%$ in the examined Roumy, white and cheddar cheese respectively in (fig. 4).
Four different serotypes of $E$. coli were identified, E. coli $\mathrm{O}_{111}: \mathrm{H}_{4}(29.41 \%)$; E. coli $\mathrm{O}_{124}: \mathrm{H}(17.65 \%)$; E. coli $\mathrm{O}_{127}: \mathrm{H}_{6}(23.53 \%)$ and E. coli $\mathrm{O}_{55}: \mathrm{H}_{7}$ (29.41\%) (fig. 5). The results from PCR examination of the different serotypes of $E$. coli revealed that only E. coli $O_{127}: H_{6}$ had expressed both toxin producing genes, while $E$. coli $O_{111}: H_{4}$ had expressed only stx 1 gene, however, both $E$. coli $O_{124}: H$ and $O_{55}: H_{7}$ had expressed stx2 gene (fig. 6).

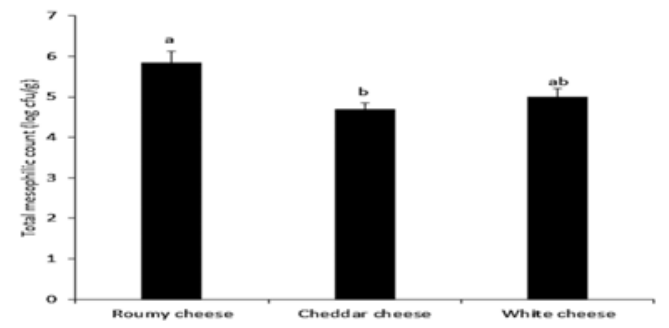

Figure 1. Total mesophilic count in different cheese types marketed in Zagazig city. Total mesophilic count in the different examined cheese types marketed in Zagazig city, Egypt. Values represent means \pm SD (Log $\mathrm{cfu} / \mathrm{g})$ of twenty-five samples for each type and each sample was measured in duplicates. Columns with different letters differ significantly at $P<0.05$.

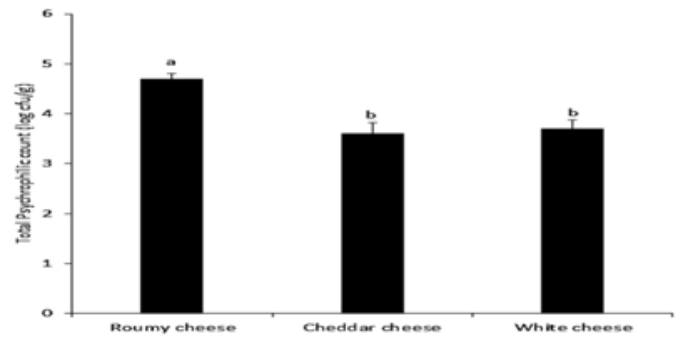

Figure 2 Total psychrophilic count in different cheese types marketed in Zagazig city. Total psychrophilic count in the different examined cheese types marketed in Zagazig city, Egypt. Values represent means \pm SD (Log $\mathrm{cfu} / \mathrm{g}$ ) of twenty-five samples for each type and each sample was measured in duplicates. Columns with different letters differ significantly at $\mathrm{P}<0.05$.

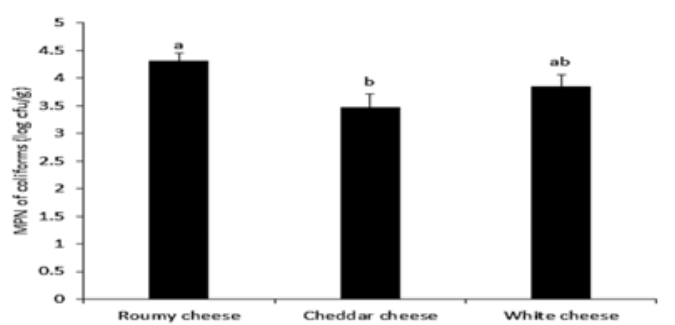

Figure 3. Most Probable Number (MPN) of coliforms in different cheese types marketed in Zagazig city. Most Probable Number of coliforms in the different examined cheese types marketed in Zagazig city, Egypt. Values represent means $\pm \mathrm{SD}(\mathrm{Log} \mathrm{cfu} / \mathrm{g})$ of twenty-five 
samples for each cheese type. Columns with different letters differ significantly at $\mathrm{P}<0.05$.

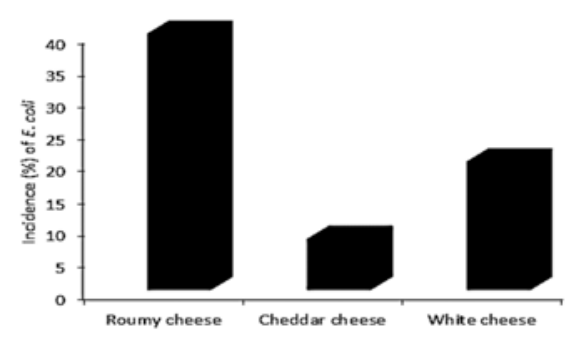

Figure 4. Incidence (\%) of $E$. coli isolated from different cheese types marketed in Zagazig city.

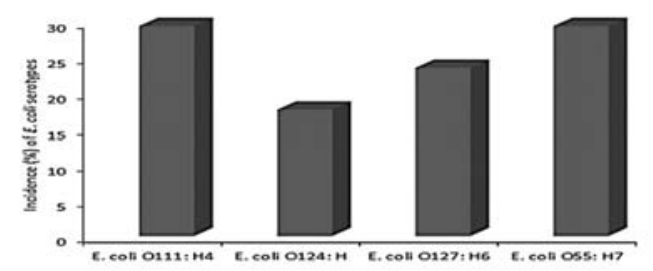

Figure 5. Incidence (\%) of different identified E. coli serotypes isolated from different cheese types marketed in Zagazig city.

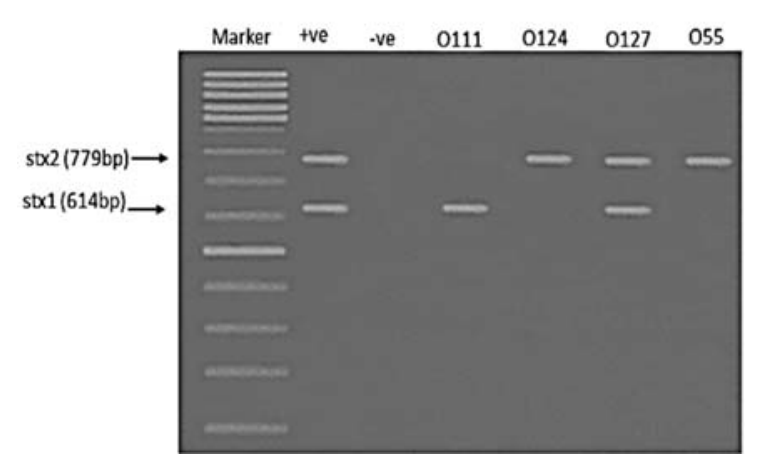

Figure 6. DNA expression of shiga-toxins producing genes (stx1 \& stx2) in the identified E. coli serotypes isolated from different cheese types marketed in Zagazig city

\section{DISCUSSION}

Dairy products like cheese represent an important part of the food menu not only in Egypt but also in the other parts of the world. Thus, investigating the food-borne microbiological hazards due to consumption of such products is a matter of a great importance.

Aerobic plate count (APC) is considered an index of quality, which gives an idea about the hygienic measures during processing and helps in the determination of the keeping quality of the product (APHA, 2001). APC is a test to detect all viable microorganisms that could grow aerobically; it could reflect the general hygiene condition of a sample.

In this study, APC was represented by total mesophilic count and total psychrophilic count (fig. 1 and 2).

The obtained results in (fig. 1and 2) revealed that Roumy cheese had significantly higher total mesophilic and psychrophilic count which may be attributed to the use of raw milk with high microbial load in cheese manufacture and uncontrolled ripening conditions.

In line with our findings, Little et al. (2008) reported unsatisfactory hygienic measures for retail cheeses made from raw, thermized or pasteurized milk in the United Kingdom. However, the recorded counts in this study were lower than that reported by Hayaloglu and Kirbag (2007) who recorded a total mesophilic count ranged from 8.26 to $10.69 \log \mathrm{cfu} / \mathrm{g}$ in the kuflu cheeses.

Coliform bacteria are commonly found in the intestine of animals. A specific subgroup of coliform bacteria is fecal coliform bacteria, with the most common member in the subgroup being $E$. coli.

The presence of fecal coliform bacteria indicates that samples may be fecal contaminated. Positive results of fecal coliform or E.coli in the samples may indicate the existence of other pathogenic organisms, thus reflecting the potential health risks for individuals being exposed to samples. Contamination of ready to eat food is attributed to post-processing contamination due to many reasons such as unhygienic practices during food handling, lack of personal hygiene, unhygienic kitchen, utensils, equipment and packaging (Darwish et al., 2015).

We further identified four different serotypes of pathogenic E. coli namely, E. coli $\mathrm{O}_{111}: \mathrm{H}_{4}$ (29.41\%); E. coli $O_{124}: H(17.65 \%)$; E. coli $O_{127}: H_{6}$ $(23.53 \%)$ and $E$. coli $\mathrm{O}_{55}: \mathrm{H}_{7}(29.41 \%)$.

The presence of $E$. coli in cheese might be attributed to fecal contamination, poor hygienic practice of cheese handlers, faults during processing (Tebbut, 1999).

Several types of $E$. coli strains may cause gastrointestinal illness in humans. Among all of them, Shiga-toxin producing E. coli (STEC) have recently emerged as important food-borne pathogens, especially $\mathrm{O}_{157}, \mathrm{O}_{26}, \mathrm{O}_{103}, \mathrm{O}_{111}, \mathrm{O}_{145}$, $\mathrm{O}_{45}, \mathrm{O}_{55}, \mathrm{O}_{91}, \mathrm{O}_{113}, \mathrm{O}_{121}$ and $\mathrm{O}_{128}$ serogroups (Momtaz and Jamshidi, 2013).

In this study, the expression of shiga-toxin producing genes (stx1 \& stx2) in the identified serotypes was examined using multiplex PCR and the obtained results revealed that only E. coli $\mathrm{O}_{127}: \mathrm{H}_{6}$ had expressed both toxin producing genes, 
while $E$. coli $O_{111}: H_{4}$ had expressed only stx 1 gene, however, both $E$. coli $\mathrm{O}_{124}: \mathrm{H}$ and $\mathrm{O}_{55}: \mathrm{H}_{7}$ had expressed stx2 gene (fig. 6).

STEC represents a hazardous public health problem worldwide causing various human gastrointestinal tract diseases, including watery or bloody diarrhea and might develop a lifethreatening disease, such as hemorrhagic colitis, Thrombotic Thrombocytopenic Purpura and Hemolytic Uraemic Syndrome. The latter is characterized by thrombocytopenia, microangiopathic hemolytic anaemia and acute renal failure (Pennington, 2010).

In conclusion, bacterial contamination of cheese marketed in Zagazig city, Egypt, was clearly observed in this study indicating unsatisfactory hygienic measures adopted during cheese manufacture. Thus, strict hygienic measures should be followed during the processing of different dairy products in Egypt to avoid the unwanted microbial contamination in the end dairy products.

\section{REFERENCES}

American Public Health Association (APHA), 2001. Compendium of methods for the microbiological examination of food, 4th ed. American Public Health Association, Washington, D.C., USA.

Anonymous, 2000. Outbreak of Escherichia coli O157:H7 infection associated with eating fresh cheese curds-Wisconsin. June 1998. MMWR 49, 911-913.

Darwish, W.S., Eldin, W.F.S., Eldesoky, K.I., 2015. Prevalence, Molecular Characterization and Antibiotic Susceptibility of Escherichia Coli Isolated from Duck Meat and Giblets. J Food Safety 35, 410-415.

Dhanashree, B., Mallya, P.S., 2008. Detection of shiga-toxigenic Escherichia coli (STEC) in diarrhoeagenic stool \& meat samples in Mangalore, India. Indian J Med Res 128, 271-277.
Hayaloglu, A.A., Kirbag, S., 2007. Microbial quality and presence of moulds in Kuflu cheese. Int J Food Microbiol 115, 376-380.

International Commission on Microbiological Specifications for Foods (ICMSF), 1996. Microorganisms specification of food pathogens.Vol.2. Chapman and Hall, Landon, New York, USA.

Jay, J.M., 1992. Modern food microbiology, 4th ed. Chapman and Hall, New York.

Kok, T., Worswich, D., Gowans, E., 1996. Some serological techniques for microbial and viral infections. In Practical Medical Microbiology, (J. Collee, A. Fraser, B. Marmion and A. Simmons, eds.), 14th ed. Edinburgh, UK, Churchill Livingstone.

Little, C.L., Rhoades, J.R., Sagoo, S.K., Harris, J., Greenwood, M., Mithani, V., Grant, K., McLauchlin, J., 2008. Microbiological quality of retail cheeses made from raw, thermized or pasteurized milk in the UK. Food Microbiology 25, 304-312.

Momtaz, H., Jamshidi, A., 2013. Shiga toxinproducing Escherichia coli isolated from chicken meat in Iran: serogroups, virulence factors, and antimicrobial resistance properties. Poult Sci 92, 1305-1313.

Pennington, H., 2010. Escherichia coli O157. Lancet 376, 1428-1435.

Ranganathan, R., Nicklas, T.A., Yang, S., Berenson, G.S., 2005. The nutrition impact of dairy product consumption on dietary intakes of adults (1995-1996): The Bogalusa Health Study. J. Am. Diet Assoc. 105, 13911400.

Scallan, E., Hoekstra, R.M., Angulo, F.J., Tauxe, R.V., Widdowson, M.A., Roy, S.L., Jones, J.L., Griffin, P.M., 2011. Foodborne Illness Acquired in the United States-Major Pathogens. Emerging Infectious Diseases 17, 7-15.

Tebbut, G.M., 1999. Comparison of traditional and rapid method for assessing the risk of bacterial cross- contamination from cutting boards. Int. J. Environ. Health Res. 9, 67-74. 